\title{
Rastros biopolíticos del franquismo. La homosexualidad como "peligrosidad social" según las sesiones de la Comisión de Justicia española en 1970
}

\section{Traces of Francoist Biopolitics. Homosexuality as "social dangerousness" according to the Spanish Justice Commission sessions in 1970}

\author{
VÍCTOR MORA GASPAR \\ Universidad Autónoma de Madrid \\ victorl.mora@predoc.uam.es
}

\begin{abstract}
Resumen: En enero de 1970 se planteó en las Cortes españolas un proyecto de ley denominado "Peligrosidad y Rehabilitación Social". La que iba a ser una ley de carácter preventivo del delito, se propuso como sustitución y modernización de la denominada Ley de Vagos y Maleantes de 1933, modificada en el año 1954 para incluir la figura de los homosexuales como sujetos potencialmente peligrosos para la sociedad y el "bien común". Este proyecto de ley, que incluía otras figuras como "prostitutas, pornógrafos y proxenetas", fue redactado por el magistrado juez del Tribunal de Vagos y Maleantes de Cataluña y Baleares, Antonio Sabater Tomás, y debatido durante los meses de junio y julio por, entre otros, la fundadora de la Sección Femenina de Falange, Pilar Primo de Rivera. Las disputas mantenidas durante aquellas sesiones de la Comisión de Justicia determinaron el lenguaje específico sobre el que después se basarían las denuncias y condenas de miles de personas. La promulgación de la Ley de Peligrosidad y Rehabilitación Social, aprobada en agosto de 1970, constituyó asimismo un factor precipitante de la lucha organizada por la liberación homosexual en España, colectivo que luchó desde ese mismo año, entre otras cosas, por su derogación.
\end{abstract}

Palabras clave: Peligrosidad social, estudios de género, biopolítica, franquismo, homosexualidad.

Abstract: In January 1970 a bill called "Dangerousness and Social Rehabilitation" was proposed in the Spanish Court to debate. It was a preventive crime law, proposed as a substitution and modernization of an old law from 1933 which was modified in 1954 to include "homosexuals" as potentially dangerous subjects for society and for "common good". This bill, which included other figures such as prostitutes, pornographers and procurers, was written by the magistrate judge Antonio Sabater Tomás, and it was debated

Recibido: 29 de agosto de 2018; aceptado: 16 de diciembre de 2018; publicado: 30 de marzo de 2019.

Revista Historia Autónoma, 14 (2019), pp. 173-193

e-ISSN: 2254-8726; DOI: https://doi.org/10.15366/rha2019.14.009

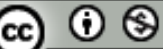


during the months of June and July by, among others, Pilar Primo de Rivera, who was the founder of Falange Female Section. The disputes held during those sessions of the Justice Commission determined the specific language on which the allegations and convictions of thousands of people would later be based. The enactment of the Law on Danger and Social Rehabilitation, approved in August 1970, was also a precipitating factor for the rise of homosexual activism in Spain, which fought collectively since that same year, among other things, for the abolition of this law.

Keywords: Social dangerousness, gender studies, biopolitics, Francoism, homosexuality.

\section{Introducción, metodología y estado de la cuestión. Biopolítica y género en el franquismo}

1970 es un año especialmente interesante en la historia reciente española, ya que supone lo que podría ser el eje central del periodo gozne que comprende el llamado tardofranquismo y los albores de la transición a la democracia. Durante esta breve etapa de cambio social, cultural y político, en la que las fuerzas de oposición al régimen se hacían cada vez más notables, las autoridades franquistas reelaboraban estrategias de represión y control de la población con la intención de adaptarlas al nuevo contexto. El proyecto de ley de Peligrosidad y Rehabilitación Social (LPRS), que tipificaba de manera pormenorizada a los sujetos potencialmente peligrosos para el bien común, es un ejemplo de la voluntad del régimen de Franco por renovar su estrategia biopolítica.

El desarrollo e imposición de unos modos de clasificación y comportamiento para los cuerpos, organizado, estructurado y naturalizado desde las esferas de poder, es lo que podemos llamar aquí biopolítica. Y, para el periodo que se trabaja en este texto, es útil entender la idea de biopolítica como el intento administrativo de controlar al cuerpo social como un organismo ${ }^{1}$. Como explica Ugarte, a propósito del caso español, "las autoridades inauguraron la biopolítica al convertir la existencia en bien común mientras instauraban biopoderes que organizaban la salud pública" ${ }^{2}$. La población bajo el régimen sería comprendida como un todo, como un cuerpo de cuya buena salud la gestión política debía ocuparse. Por tanto, la voluntad de clasificar y "rehabilitar" (o "extirpar" en última instancia) las partes contaminadas del cuerpo social no es sino el ejercicio y la expresión de los biopoderes franquistas.

\footnotetext{
1 "La biopolítica tiene, por un lado, la misión de reconocer los riesgos orgánicos que amenazan al cuerpo político, y, por el otro, la de individualizar, y preparar los mecanismos de defensa para hacerles frente, arraigados también en el terreno biológico." Esposito, Roberto, Bíos. Biopolítica y filosofía, Madrid-Buenos Aires, Amorrortu, 2011, p. 31 .

"En un primer momento tales desarrollos se limitaron a medidas de higiene y asepsia.", Ugarte, Javier, "Nacimiento del biopoder", en Eikasia. Revista de filosofia, 75 (2017), p. 27.
} 
Durante la dictadura, la praxis totalitaria pretendió definir la españolidad y lo social español mediante opositivos absolutos y utilizó, entre otras, la estrategia de definir como patológico lo que consideraba antiespañol. En este caso vamos a ver un ejemplo de lo que el sistema franquista catalogó como anómalo en lo que respecta a la sexualidad, pero las prácticas clasificatorias del régimen fueron mucho más allá de esos límites (por ejemplo, llegó a tildar de "enfermedad mental" la ideología marxista³). En este artículo se presenta un análisis de la configuración de la "homosexualidad" como peligrosidad social durante los debates de la Comisión de Justicia española de 1970. El "homosexual" (o el "invertido", que en el lenguaje hegemónico de la dictadura y su lógica reduccionista eran términos que englobaban en realidad múltiples y diversas experiencias del espectro del género y la sexualidad, como veremos) era considerado un enemigo de carácter social. La jurisprudencia franquista trataba de distinta manera la criminalidad política y la peligrosidad social, "incluyéndose en el primer caso a separatistas, anarquistas, comunistas y demás izquierdistas, y en el segundo a los por entonces llamados vagos y maleantes, a las prostitutas y los homosexuales"`. Poner el foco de atención en las sexualidades marginales, abyectas o disidentes es fundamental porque "justamente son esas sexualidades las que nos ayudan a entender cómo funciona el poder y el privilegio en todas las sexualidades y en todas las personas" ${ }^{5}$. El debate de las Comisiones constituye, precisamente, un ejemplo de los intentos del poder franquista por clasificar y ordenar los cuerpos de manera jerárquica. Y un análisis de su desarrollo permitirá comprobar si quedan elementos vivos de aquella lógica, si perduran huellas o rastros de esa voluntad biopolítica y si, quizá, condicionan nuestra mirada a la hora de referir u organizar un discurso sobre sexualidades.

La homosexualidad masculina, considerada opositivo absoluto a la construcción del ideal franquista del "hombre viril" y construida como categoría de identidad patológica, debía ser separada de la sociedad, en cuanto contaminante, contagiosa y perjudicial para el bien común. Por tanto, dadas las características del objeto de estudio, es adecuado asumir una aproximación metodológica transdisciplinar y utilizar recursos propios de investigación historiográfica, análisis del discurso y teorías del género.

Como marco teórico es interesante recuperar lo que propone Foucault en La voluntad de saber ${ }^{6}$ cuando explica que la sexualidad, como dispositivo convencional de regulación del comportamiento y las relaciones humanas, es un elemento que se encuentran en constante movimiento; en un movimiento paralelo, podríamos decir, al acontecer político que las sociedades desarrollan a lo largo del tiempo. Cada comunidad política, en los distintos

\footnotetext{
$\overline{{ }^{3} \text { Vallejo Nágera, }}$ psiquiatra oficial del régimen, fue el encargado de experimentar con presos políticos en campos de concentración para buscar el llamado «gen rojo». Bandrés, Javier, y Rafael Llanova, "La psicología en los campos de concentración de Franco", en Psicothema, 8, 1 (1996), pp. 1-11. Sobre la práctica biopolítica franquista consultar las obras citadas de Ugarte y Cayuela Sánchez.

${ }^{4}$ Martín Martín, Sebastián, "Criminalidad política y peligrosidad social en la España contemporánea (1870-1970)", en Quaderni Fiorentini per la storia del pensiero giuridico modern, 38, 1 (2009), p. 869.

${ }^{5}$ Platero, Lucas, "Introducción. La interseccionalidad como herramienta de estudio de la sexualidad", en Platero, Lucas (ed.), Intersecciones: cuerpos y sexualidades en la encrucijada, Barcelona, Bellaterra, 2012, p. 18.

${ }^{6}$ Foucault, Michel, Historia de la sexualidad. Vol. I. La voluntad de saber, Madrid, Siglo XXI, 1998.
} 
momentos históricos, produce una serie de conocimientos y prácticas (lo que denomina "saberes y poderes") que explican, naturalizan e imponen unas relaciones y performances de género y sexualidad estandarizadas ${ }^{7}$, y pretenden definir de esta forma el carácter de la propia comunidad. La participación en la vida pública, en la polis, siempre es una participación mediada y estructurada por lo político, y en esa mediación se encuentra el espectro sexogenérico ${ }^{8}$, que condiciona, limita y atraviesa los cuerpos que componen la sociedad. En este sentido se puede afirmar que el sexo es siempre político, pero "hay períodos históricos en los que la sexualidad es más intensamente contestada y más abiertamente politizada. En tales períodos, el dominio de la vida erótica es, de hecho, renegociado".

Respecto al marco temporal que nos ocupa, es especialmente útil recuperar la propuesta de Cayuela Sánchez, que divide el franquismo en dos periodos fundamentales según su organización económica y política, condicionada por la situación internacional y con un consecuente y grave impacto social. En 1970, el llamado "franquismo desarrollista", "periodo singularizado por la llegada a España del neocapitalismo, el nacimiento de una incipiente sociedad de consumo [y] una creciente movilización social"10, se encontraba ampliamente avanzado. Y para esta etapa (cuyo comienzo data Cayuela en 1959) las estrategias de control biopolítico del cuerpo nacional se habían sometido a revisión y cambio. El proyecto de la LPRS se ocupaba, entre otras cuestiones, de revisar y redefinir los estados de peligrosidad, entre los que obtuvo especial atención la homosexualidad ${ }^{11}$. Sin embargo, la condena de la disidencia sexual estaba en el punto de mira de la normatividad franquista desde mucho antes.

La dictadura española, de estructura totalitaria y esencia nacionalcatólica, sometió, desde el principio, a los dispositivos sexogenéricos a un control severo mediante la actuación de distintas instituciones. Desde un marcado binarismo absolutista, la feminidad y la masculinidad debían quedar perfectamente definidas en cuerpos coherentes, que ocuparían, además, unos lugares determinados en la distribución social. El franquismo, como sistema, se desarrolla sobre una estructura de base misógina ${ }^{12}$ : las mujeres quedan relegadas a complemento del varón y el espectro de lo femenino se considera una degradación. La construcción cultural de la

\footnotetext{
${ }^{7}$ El género y la sexualidad como "performativo" se entiende como el producto de la repetición de códigos sociales estructurales que configuran y dotan de significado a la identidad en cada contexto histórico. Ver Butler, Judith, El género en disputa. Feminismo y subversión de la identidad, Barcelona, Paidós, 2007.

${ }^{8}$ Bell, David y Jon Binnie, The Sexual Citizen. Queer Politics and Beyond, Oxford-Cambridge-Massachusetts, Polity Press \& Blackwell Publishers, 2000, p. 10.

${ }^{9}$ Rubin, Gayle, "Reflexionando sobre sexo. Notas para una teoría radical de la sexualidad", en Vance, Carole S. (comp.), Placer y peligro. Explorando la sexualidad femenina, Madrid, Revolución, 1989, p. 113.

${ }^{10}$ Cayuela Sánchez, Salvador, Por la grandeza de la patria. La biopolítica en la España de Franco (1939-1975), Madrid, Fondo de Cultura Económica de España, 2014, pp. 39-40.

${ }^{11}$ Para el tema que se aborda resultan fundamentales además los trabajos citados de investigadores españoles sobre las sexualidades no normativas durante el franquismo; y especialmente importantes las recientes investigaciones sobre la memoria específica de la disidencia sexual durante la dictadura y la transición de Huard y de Chamouleau, que abordan desde nuevas ópticas el nacimiento y desarrollo de la lucha organizada a partir precisamente de la puesta en vigor de la LPRS y problematizan las complejas cuestiones de la identidad, el sujeto político y el desarrollo del mismo en el proceso de transición a la democracia.

${ }^{12}$ Lo que Olmeda denomina el "machismo orgánico" estructural del franquismo. Ver Olmeda, Fernando, La pluma y el látigo. Homosexuales en la España de Franco, Madrid, Anaya, 2004, p. 34.
} 
masculinidad española ha estado tradicionalmente vinculada a los controvertidos estereotipos del macho y el machismo, cuyo origen heterosexista se encuentra en mitos fundadores de la cultura popular ${ }^{13}$. El franquismo recupera la idea de masculinidad viril en oposición absoluta a lo femenino, y la enarbola como síntesis fundacional de su identidad. La condición de existencia de la masculinidad normativa será precisamente la ocultación y el rechazo de lo femenino y del afeminamiento ${ }^{14}$. Entre las ideas que el régimen franquista reproducía a través de su sistema propagandístico se encontraba la de recuperar el "clásico espíritu español”, que consideraba perdido por la "degeneración” de la República. Era frecuente, incluso antes de la guerra, que desde ciertos sectores conservadores y reaccionarios se llamara la atención sobre el feminismo, el auge de visibilidad de los invertidos y las vanguardias artísticas como amenazas a la masculinidad hegemónica, definida como garante del orden y la estabilidad ${ }^{15}$.

En uno de los primeros discursos de Franco ya se encuentra la asimilación simbólica del pueblo español con la virilidad como categoría de identidad nacional esencialista ${ }^{16}$, asociada alegóricamente a elementos como la bravura, la valentía, la fuerza y la dominación. Un concepto que se repite con frecuencia en sus discursos y que se convertirá en una de las máximas del ideario franquista ${ }^{17}$. La identidad y el comportamiento de los varones y las mujeres estaban definidos y ordenados desde el principio por distintas instituciones de regulación y control, como la Iglesia y las escuelas religiosas, la Sección Femenina de Falange (SFF) ${ }^{18}$ o el Servicio Militar Obligatorio (SMO) ${ }^{19}$. Toda esta retórica, ya en la posguerra, desde los años de la autarquía en adelante, se utilizará para legitimar las políticas protonatalistas del Estado ${ }^{20}$, que formalizaban la familia heteronormativa y la sexualidad de exclusiva finalidad procreadora como la única

\footnotetext{
${ }^{13}$ Interesante trabajo sobre esta cuestión a través de análisis de ejemplos y casos en Armengol-Carrera, Josep M. (ed.), Queering Iberia. Iberian Masculnities at the Margins, New York, Peter Lang, 2012. DOI: https://doi. org/10.3726/978-1-4539-0550-0

${ }^{14}$ Una cuestión fundacional de la masculinidad en el contexto cultural hispano, como se expone en Blackmore, Josiah y Gregory S. Hutcheson (eds.), Queer Iberia. Sexualities, cultures, and crossing from the middle ages to renaissance, New York, Duke University Press, 1999, p. 3. DOI: https://doi.org/10.1215/9780822382171

${ }^{15}$ Vázquez García, Francisco Javier y Richard Cleminson, Los Invisibles. Una historia de la homosexualidad masculina en España, 1850-1939, Granada, Comares, 2011, p. 196.

16 "No queremos una vida fácil, queremos una vida dura... la vida de un pueblo viril." Citado en Mora Gaspar, Víctor, Al margen de la naturaleza. La persecución de la homosexualidad durante el franquismo. Leyes, terapias y condenas, Madrid, Debate, 2016, p. 29.

${ }^{17}$ Minardi observa que lo viril como significante está presente en multitud de expresiones del contexto pragmático franquista. Utiliza documentos tan dispares como la Revista Nacional de Educación, en la se indica que es el maestro quien "ha de troquelar al niño que va a ser hombre, y lo ha de troquelar con perfiles recios y viriles", Minardi, Adriana Elizabeth, "Funciones de la Hispanidad: ETHOS discursivo y metáfora en los mensajes de fin de año del General Francisco Franco (1939-1967)", en Butlletí de la Societat Catalana d'Estudis Històrics, 21 (2010), p. 252. DOI: https://doi.org/10.2436/20.1001.01.62

18 "Las mujeres eran entrenadas por el régimen a través de instituciones como la Sección Femenina, para ser el complemento y sustento del varón, las sostenedoras del hogar quienes guardan y hacen posible el reposo del guerrero y su prole. A través del control social y las normas imperantes, se aseguraba la sumisión de la ciudadanía. La sumisión de las mujeres en particular era vital para el mantenimiento económico y político del régimen, que contó con la ayuda precisa de la Iglesia y la Psiquiatría, entre otras instituciones.", Platero, Lucas, "Lesboerotismo y la masculinidad de las mujeres en la España franquista", en Bagoas-Estudos gays: gêneros e sexualidades, 2, 3 (2012), p. 18.

${ }^{19}$ Sistema de homogeneización ideológica que además adoctrinaba en la masculinidad como severa, dominante y violenta en oposición al enemigo feminizado. Un estupendo análisis en Alcalde, Ángel, "El descanso del guerrero: la transformación de la masculinidad excombatiente franquista (1939-1965)", en Historia y Política, 37 (2017), pp. 177-208. DOI: https://doi.org/10.18042/hp.37.07

${ }^{20}$ Cayuela Sánchez, Salvador, Por la grandeza... op. cit., p. 109.
} 
posible en la sociedad española. La disidencia sexual, no obstante, no fue el primer objetivo del régimen ${ }^{21}$ que, tras la devastadora guerra, concentró sus esfuerzos en perseguir y tratar de erradicar la disidencia política. Sin embargo, la represión existía, obviamente, y el miedo a la delación se convirtió en la principal herramienta de la represión cotidiana ${ }^{22}$ durante los años de la autarquía.

Finalmente, en 1954, la subalternidad sexual encuentra una enunciación legal en la reforma conocida como Ley de Vagos y Maleantes (LVM), una ley republicana preventiva del delito, que databa de 1933, y que se modifica este año para incluir la figura de los homosexuales como peligrosos. Son muchos los textos de científicos, psiquiatras, médicos y juristas españoles que trabajan para explicar los porqués de la necesidad de la penalización de la homosexualidad ${ }^{23}$, pero destaca especialmente la figura de Antonio Sabater Tomás, magistrado juez del Tribunal de Vagos y Maleantes de Cataluña y Baleares, que dedicó un gran porcentaje de su carrera a publicar textos de particular inquina contra la homosexualidad. En muchos de ellos perfila los pormenores de la relación necesaria entre dicha orientación y el crimen:

\footnotetext{
Se trata de sujetos celosos, sádicos, brutales, con manía persecutoria, que castigan, van armados, amenazan de muerte y a veces matan, todo ello producto de su posición homosexual que no logran dominar [...]. Es el grupo de mayor criminalidad y delincuencia. No sólo desconocida, sino negada su condición de enfermedad, pasan por la vida... dejando una estela de amarguras, de desesperaciones, de dolores, hasta el día en que el choque es más violento y se habla de perturbación o criminalidad. Prácticamente son los más peligrosos [...]. Se originan en ellos fantasías inconscientes de apuñalar y estrangular. ${ }^{24}$
}

Se encarga además de insistir en la idea de la contagiosidad homosexual y de la alarma social que tal peligro debería causar. Sabater Tomás representa una corriente represora del género y el sexo que trataba de convertir en patológicas y criminales a las identidades que no encajaran con el patrón sexogenérico normativo, impuesto por la doctrina nacionalcatólica. Los textos más relevantes de Sabater Tomás forman parte de esa segunda etapa del franquismo que identifica Cayuela, en la que el nuevo marco de relaciones internacionales exigía al Gobierno español una reevaluación de sus estrategias de control de cara a la población. Nuevos retos,

\footnotetext{
${ }^{21}$ Monferrer Tomás, Jordi M., Identidad y cambio social. Transformaciones promovidas por el movimiento gay/ lesbiano en España, Barcelona - Madrid, Egales, 2010, pp. 54-55.

${ }^{22}$ Sobre la eficacia de la delación como deber patriótico y el terror que supuso su imposición. Ver García García, Jordi y Miguel Ángel Ruíz Carnicer, La España de Franco (1939- 1975) Cultura y vida cotidiana, Madrid, Síntesis, 1999.

${ }^{23}$ Para ampliar sobre este tema ver Mora Gaspar, Víctor, Al margen de la naturaleza... op. cit. y Molina Artaloyita, Francisco, Estigma, diagnosis e interacción: Un análisis epistemológico y axiológico de los discursos biomédicos sobre la homosexualidad en los regímenes autoritarios ibéricos del siglo $\mathrm{XX}$, tesis doctoral, Universidad nacional de Educación a Distancia, 2015.

${ }^{24}$ Sabater Tomás, Antonio, Gamberros, homosexuales, vagos y maleantes, Barcelona, Hispano Europea, 1962, pp. $183-184$
} 
como la contaminación provocada por el "turismo degenerado" ${ }^{25}$, preocupaban a médicos ${ }^{26}$ y a magistrados y juristas como Sabater Tomás, que identifica entre sus consecuencias una "creciente ola de homosexualismo".

\section{La homosexualidad como "peligrosidad social" en las sesiones de la Comisión de Justicia española en 1970}

El Ministerio de Justicia, como consecuencia de esta corriente de pensamiento, nombra una Comisión encargada de la reforma de la LVM por orden de 4 de octubre de 1967. Un equipo de cinco magistrados (entre los que se encontraba Sabater Tomás) fueron los encargados de redactar el anteproyecto de esta ley, que sería sometido a análisis y debate durante dos meses en la Comisión de Justicia de las Cortes.

Además de la LVM, o la todavía embrionaria LPRS, la figura del escándalo público, tipificada en el artículo 431 del Código Penal, servía de cajón de sastre para condenar y penalizar todo aquello "que ofende al pudor o las buenas costumbres con hechos de grave escándalo o trascendencia". Dicho esto, conviene puntualizar que estas leyes se aplicaban a la homosexualidad masculina. Las lesbianas, cuya sexualidad no era contemplada, fueron ignoradas en la redacción de los supuestos punibles. El silencio en torno a estas cuestiones ha dificultado sobremanera la investigación sobre la represión a las lesbianas ${ }^{27}$. Sobre este tema, Platero señala que las mujeres masculinas eran tan visibles como los hombres afeminados "y la asociación típica de lesbianismo (o transexualidad) y masculinidad hace que sean percibidas como muy peligrosas y por tanto con necesidad de ser reguladas, castigadas y normativizadas" 28 . Lo cierto es que el hecho de que la ley ignorase a las lesbianas como sujeto específico de castigo (o la considerase por defecto dentro de los "actos de homosexualidad" y por tanto contribuyese a una invisibilización de tales experiencias y subjetividades dentro de un genérico masculino) no quiere decir que no se las persiguiese y castigase con dureza; de hecho, tal invisibilización y sus consecuentes vacíos en la representación legal contribuyeron al desarrollo de arbitrariedad y abusos en los castigos y formas de represión de mujeres lesbianas ${ }^{29}$. Las leyes que se trabajan

\footnotetext{
${ }^{25}$ Huard, Geoffroy, Los antisociales. Historia de la homosexualidad en Barcelona y París, 1945-1975, Madrid, Marcial Pons, 2014, p. 100.

${ }^{26}$ El doctor López Ibor constituye otro ejemplo de discurso científico hegemónico preocupado por las "costumbres y modos extranjeros" que representan una desviación, ya que "disfrazadas de caballo de Troya, una vez dentro, rompería los auténticos cimientos de la sociedad cristiana", López Ibor, Juan José, El español y su complejo de inferioridad, Madrid, Ediciones Rialp, 1970, p. 262.

${ }^{27}$ Aliaga, Juan Vicente y José Miguel García Cortés, Identidad y diferencia. Sobre la cultura gay en España, Barcelona - Madrid, Egales, 1997.

${ }^{28}$ Platero, Lucas, "Lesboerotismo y la masculinidad de las mujeres... op. cit., p. 34.

${ }^{29}$ Juliano, Dolores, "Tiempo de cuaresma. Modelos de sexualidad femenina bajo el franquismo", en Osborne, Raquel (ed.), Mujeres bajo sospecha. Memoria y sexualidad 1930-1980, Madrid, Fundamentos, 2012, p. 40.
} 
y se analizan aquí sirvieron para criminalizar, perseguir y encarcelar, sobre todo, a varones homosexuales y mujeres transexuales ${ }^{30}$, pues la represión a las lesbianas iba por otros cauces: sus propias familias, que las denunciaban e internaban, o la Iglesia Católica ${ }^{31}$.

Las reuniones en la Comisión de Justicia para debatir los pormenores de la LPRS se alargaron durante meses. En esta comisión se encontraba Pilar Primo de Rivera. La que fue fundadora de la SFF en 1934, se ocupó en este grupo de trabajo de aspectos relacionados con la prostitución, ya que las trabajadoras sexuales eran también objeto de debate en cuanto peligrosas sociales. Como representante de los valores de la SFF, Primo de Rivera se encontraba en esta Comisión como símbolo de la tenaz salvaguarda de los valores sociales que su institución había representado durante el periodo de la dictadura ${ }^{32}$. La SFF fue un organismo muy interesante y complejo para la organización de las mujeres en el fascismo español, que, al mismo tiempo, constituyó un instrumento para la difusión de la propaganda pronatalista ${ }^{33}$ de corte católico y fascista. Concebía el aborto como un "crimen contra la raza", al igual que anunciar o vender anticonceptivos ${ }^{34}$, por lo que su voz como representante de este modelo de conducta de género y sexo era del todo pertinente en este debate legal. Primo de Rivera, con una remarcada inclinación hacia el cuidado, insiste desde el principio en que la ley debería llamarse "Ley de Rehabilitación Social" y ocuparse fundamentalmente de esa rehabilitación. Considera un problema centrarse en la peligrosidad, porque eso sería continuista. Cambiaría la nomenclatura de la LVM, pero no modificaría ni el contenido, esencialmente punitivo, ni la función; lo que le lleva a afirmar (insistiendo por tercera vez en la sesión):

\footnotetext{
Que la ley no fuera sólo negativa, en el sentido de castigar, castigar y castigar, sino que fuera también de rehabilitar, porque hay que considerar que muchos de estos peligrosos sociales lo son, a lo mejor, por las circunstancias familiares en que han vivido, por las malas compañías en una edad temprana, por el ambiente social, o por lo que sea. ${ }^{35}$
}

No obstante, su apreciación no cala, y por fin el señor Gómez de Aranda le responde, con manifiesto ánimo de zanjar su petición para continuar con otros asuntos de la ley:

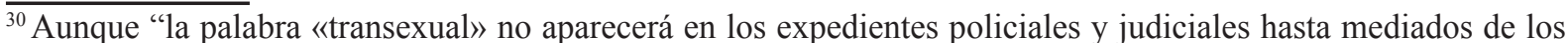
años 70. Anteriormente la manera más normal de calificar a las transexuales en los expedientes franquistas era la de «invertidos con pechos»". Bedoya, Víctor, "El franquismo contra las transexuales: expedientes policiales y judiciales", en Osborne, Raquel (ed.), Mujeres bajo sospecha ... op. cit., p. 166.

${ }_{31}$ Trujillo, Gracia, "Archivos incompletos. Un análisis de la ausencia de representaciones de masculinidades femeninas en el contexto español”, en Mérida Jiménez, Rafael y Jorge Luis Peralta (eds.), Las masculinidades en la Transición, Barcelona - Madrid, Egales, 2015, p. 45.

${ }^{32}$ La SFF comenzó a funcionar antes de la guerra, en 1934, un año después de que José Antonio Primo de Rivera fundara la Falange Española. La SFF permanecerá activa hasta 1977.

${ }^{33}$ Las organizaciones sociales que han censurado toda forma de relación sexoafectiva y erótica parten de voluntades biopolíticas pronatalistas, con diferentes fines y preocupaciones en torno al crecimiento de la población. Ver Ugarte, Javier, Placer que nunca muere. Sobre la regulación del homoerotismo occidental, Barcelona - Madrid, Egales, 2014.

${ }^{34}$ Huard, Geoffroy, Los antisociales. Historia... op. cit., p. 43.

${ }^{35}$ Boletín Oficial de las Cortes Españolas, 22 de junio de 1970, apéndice núm. 76, p. 31.
} 
En cuanto a las manifestaciones de la señorita Primo de Rivera, tenemos que decirle que su preocupación es nobilísima y creo que en el texto de la ley está ya la rehabilitación. Por supuesto, que no por hacer figurar la palabra rehabilitación en el título va a cambiar el contenido de la ley. No va a acudirse a cualquier tartufismo para escamotear el contenido de la ley. El contenido es el contenido, que es lo principal. Evidentemente, el título compromete al contenido, y por eso la Ponencia ha aprovechado la oportunidad de recoger la enmienda del señor Díaz-Llanos y se dice «de peligrosidad y rehabilitación social», porque esto nos compromete a todos a que sea una ley preventiva, nunca sancionadora; jamás esta ley es sancionadora. ${ }^{36}$

Las sesiones, recogidas en el Boletín Oficial de las Cortes Españolas, son especialmente asombrosas en lo que respecta a la homosexualidad. Se aprecia una clara tensión entre los partidarios de considerar punibles solo aquellos actos que incurrieran en escándalo público y los que abogaban por la penalización per se de la homosexualidad. Primo de Rivera intervino con mayor vehemencia, como se ha indicado, en lo que refería a las trabajadoras sexuales. Sin embargo, es interesante incidir en que fue una de las voces que se sumó a la pertinencia de la "habitualidad" para considerar estados de peligrosidad, algo que afectó directamente a la estipulación de las condenas por homosexualidad.

Con la venia de la Presidencia, dijo La señorita PRIMO DE RIVERA SAENZ

DE HEREDIA: En el mismo sentido de los que antes se han manifestado, para que se quite lo de «medio de vida», porque me parece, que es injusto respecto a estas mujeres, ya que muchas de ellas se pervierten porque la sociedad las ha abandonado. Sabemos que, vienen muchas mujeres de los pueblos a colocarse, las cogen, las meten en esos sitios y estas mujeres se convierten en perdidas, pero hay otras que sabemos que lo hacen por su gusto, pero que como no es su medio de vida, no les va a pasar nada. Estoy, en principio, de acuerdo con la propuesta del señor Batlle Vázquez, que decía: «Las mujeres que habitualmente se dedican a la prostitución». Me parece mejor, porque suprime la frase «medio de vida», que me parece injusta, porque muchas son unas infelices, unas desgraciadas que caen y luego no saben cómo levantarse; pero no es que se prostituyan y sean malas mujeres. ${ }^{37}$

La reincidencia y la habitualidad se convierten en elementos clave para el ejercicio de esta ley. En lo que respecta a homosexuales, en los debates se distinguen entre dos tipos: los que lo hacen por "vicio o necesidad" (económica) y los "enfermos", es decir, los que han nacido así y que, según indican varios ponentes, son una minoría. El procurador Díaz Llanos y el marqués de Valdeiglesias, participantes activos de esta Comisión, manifestaron que la ley no debía entrar en el ámbito privado, y este último añadió que "tenga las aficiones que tenga, ha de contener su

\footnotetext{
${ }^{36}$ Ibídem.

${ }^{37}$ Boletín Oficial de las Cortes Españolas, 23 de junio de 1970, apéndice núm. 77, p. 42.
} 
exteriorización, que es lo que se debe castigar" ${ }^{38}$. El periódico La Vanguardia Española se hace eco de los debates en la Comisión de Justicia sobre la LPRS, y da noticia de lo prolongado de estas conversaciones. En un apartado de este artículo sin firma, titulado "El homosexualismo y el respeto a la intimidad de la persona", se habla de la postura de Rafael Díaz Llanos, que defiende que "no se debe investigar en la vida privada ni en la intimidad de las personas porque eso puede dar lugar a «chantages» (sic.). En razón a ello propuso la atención de la ley a quienes realicen actos de homosexualidad cuando molesten a la sociedad con el escándalo y cuando dichas conductas trasciendan a la vida pública [...]. Después de esta intervención se sometió a votación el apartado, siendo aprobado por unanimidad tal como presentó la ponencia" ${ }_{39}$. En las actas de la Comisión se recoge que el señor Hernández Navarro formó parte de la oposición a esta idea y manifestó la preocupación por la condición de sujeto enfermo:

El enfermo homosexual en principio puede ser un peligro para la sociedad, ya que puede o no reprimir las consecuencias de su enfermedad. No tengo la experiencia profesional que el señor Díaz-Llanos. También estoy por encima de ese mal a Dios gracias, pero tengo cierta experiencia y he conocido casos. Los que practican hoy día actos de homosexualidad, que no son enfermos homosexuales, normalmente hacen esta figura «in crescendo» que ha contemplado en el año 1966 ó 1967 la Memoria de la Fiscalía del Tribunal Supremo, como es la prostitución de los varones, que se va manifestando de la adolescencia a los veintitantos años. Esta actividad es de varones con otros varones, precisamente con los enfermos homosexuales. ${ }^{40}$

Los "actos" ocuparán parte de las discusiones en distintos días porque atienden a factores como la prostitución masculina, que se penaliza como "acto de homosexualidad", con independencia de la orientación. Esta deriva del debate lleva a Hernández Navarro a señalar lo siguiente:

Ya no tendríamos que hacer la diferenciación de que no son homosexuales,
sino que practican actos de homosexualidad; porque habíamos llegado a la
conclusión de que se podía ser homosexual y no practicar la homosexualidad,
y que se podían practicar actos de homosexualidad sin serlo. (Rumores). ${ }^{41}$

Finalmente figuró en la ley el concepto de "actos de homosexualidad", algo que dejaba nuevamente al acusado o acusada de peligrosidad en situación de contingencia ${ }^{42}$. Sin embargo,

\footnotetext{
${ }^{38}$ Citado en Domingo Loren, Victoriano, Los homosexuales frente a la ley. Los juristas opinan, Barcelona, Plaza \& Janes, 1977, p. 43.

39 "Continuación de los debates en torno a la ley de Peligrosidad y Rehabilitación Social”, 24 de junio de 1970, La Vanguardia Española, Tisa Ediciones, p. 8.

${ }^{40}$ Boletín Oficial de las Cortes Españolas, 23 de junio de 1970, apéndice núm. 77, p. 29.

${ }^{41}$ Boletín Oficial de las Cortes Españolas, 2 de julio de 1970, apéndice núm. 86, p. 12.

${ }_{42}$ "Además de exigir que se probara que se estaba incurso en un estado de peligrosidad, se debía apreciar una peligrosidad social (artículo 2, B); naturalmente esta consideración quedaba en manos de la autoridad judicial. Una duda que se suscitó inmediatamente fue cuál era el concepto de peligrosidad, porque ni la LPRS ni su posterior Reglamento [...] se detuvieron en definirla, acudiéndose mayormente a la jurisprudencia para obtener respuesta."
} 
lo que cabe destacar es que esta resolución es la muestra de que la facción "progresista" había ganado, ya que no se penalizaba al homosexual por el hecho de serlo, sino los "actos", la reincidencia que podría causar daño social. Se enfatiza de esta forma en la voluntad rehabilitadora y no punitiva de la ley; por lo que se establece la necesidad de centros separados y personal especializado para el tratamiento y recuperación de homosexuales. No obstante, la homosexualidad ocupó varias sesiones del acalorado debate en las Cortes, y proliferaban también los argumentos que vinculaban la perversión sexual con la decadencia social y el peligro de la degeneración del país. La difusión de imágenes o de informaciones sobre estas cuestiones es un problema, porque incita a la perversión. Ese es, por tanto, el factor clave de la prevención del delito: evitar que se genere cualquier tipo de "propaganda". Un problema que enciende los ánimos de más de un procurador, que se opone a que la ley sea esencialmente rehabilitadora y que reclama la necesidad de la prevención y del castigo ejemplar como medida básica:

\begin{abstract}
Hace no mucho, un Procurador en esta sala, de gran prestigio por cierto, denunciando y comentando estas cosas, decía que en Torremolinos o en Marbella hace poco se ha celebrado un congreso de homosexuales, y nos quedamos tan tranquilos, y lo comentamos como cosa frívola, como diciendo ¡qué cosas pasan, qué desarrollados estamos! Pues bien, esa reunión no está penada en el Código Penal y tampoco está prevista en lo que hemos puesto aquí, porque el cometer actos de homosexualidad no es lo mismo que reunir un congreso y defender científicamente la homosexualidad a nivel de hombres brillantes y acomodados. Ruego a la Ponencia perdone mi apasionamiento al expresar mi convencimiento de que creo que aquí se nos ha quedado algo por decir y que conviene recoger, como un epígrafe final, lo que no está dicho en los anteriores: La inducción. ${ }^{43}$
\end{abstract}

Así habló el señor Lapiedra de Federico, quien se oponía con firmeza a la inclusión de los "actos" como elemento necesario para el castigo, ya que otros modos de propaganda como este supuesto congreso ${ }^{44}$ resultaban igualmente factores contaminantes del bien común. Sin embargo, como se ha indicado, era un debate tenso, con opiniones contrapuestas bastante equilibradas, en el que el mencionado marqués de Valdeiglesias mantuvo una posición propicia a la despenalización. Así lo demostraba cuando respondía ante el problema de los pornógrafos:

Estoy convencido, y lo he dicho aquí al tratar del caso de los homosexuales, que, hagamos lo que hagamos, no tienen cura. Por consiguiente, encerrarlos me parece una medida bastante injusta. No puedo decir lo mismo de las prostitutas, porque no estuve aquí, pero tenía pensado levantar mi voz en defensa de ellas.

\footnotetext{
Terrasa Mateu, Jordi, "Estudio jurídico de la legislación represiva franquista”, en Orientaciones. Revista de Homosexualidades, 7 (2004), p. 94.

${ }^{43}$ Ibídem, p. 13.

${ }^{44}$ No hay constancia o referencias sobre un Congreso sobre homosexualidad en Marbella o Torremolinos en los años 60; sí que eran, no obstante, destinos turísticos frecuentados por homosexuales con mayor libertad que otras zonas españolas de la época.
} 
Yo, que he defendido -digámoslo así- o que he tratado de oponerme a la inclusión de los homosexuales en esta ley y hubiera defendido a las prostitutas de haber estado presente, ahora creo que los que reparten pornografía y se dedican habitualmente a este negocio, porque es un negocio, tienen encaje exacto en esta ley que discutimos con mucho más motivo. ${ }^{45}$

A este problema se suma la observación del señor González del Yerro, director general de Instituciones Penitenciarias, sobre la reclusión de homosexuales en centros con otros presos. Cuando se propone el encarcelamiento conjunto con enfermos mentales, señala que "llevar a estos establecimientos también a los que practiquen actos de homosexualidad, considero que,

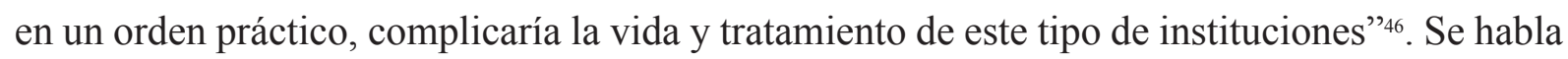
de la necesidad de centros específicos de reeducación y trabajo y, finalmente, el señor Rivas Guadilla recoge de las siguientes disposiciones propuestas:

Por eso diríamos: «a los que realicen actos de homosexualidad y, a los que habitualmente ejerzan la prostitución se les impondrá, simultánea o sucesivamente, todas o algunas de las siguientes medidas (se amplía el arbitrio judicial, se amplía también la posibilidad de la aplicación de las medidas según las circunstancias de cada sujeto):

a) Internamiento en un establecimiento de reeducación o de trabajo.

b) Prohibición de residir en el lugar o territorio que se designe.

c) Prohibición de visitar ciertos lugares o establecimientos.

d) Multa de 1.000 a 50.000 pesetas. $^{47}$

Medidas a las que el señor Fernández Carriedo, director general de Justicia, se opone con una serie de interesantes matices que, según él, se adaptan más a los cometidos de la ley: "a los llamados prostitutos, a los del género masculino que tengan estas actividades, me parece bien lo de internamiento en establecimientos de trabajo, así como la multa. Pero para los homosexuales y para las prostitutas del género femenino, creo que no debe adoptarse otro internamiento que el de regeneración, el de readaptación, y, consecuentemente, internarlos en un establecimiento de reeducación"48. A lo que Hernández Navarro responde que está de acuerdo parcialmente, ya que las multas a homosexuales resultan una medida muy eficaz que se da en la actualidad y que es bueno mantener ${ }^{49}$. El señor Gómez Aranda de Serrano, en una de las sesiones, se hacía cargo de la repercusión que el contenido de estos debates estaba teniendo en los medios y en el cuidado que debían mantener respecto al lenguaje utilizado y a las disposiciones finales.

En la Prensa se ha hablado algunas veces sobre los peligros de la Ley de

Peligrosidad. Si no tenemos un criterio realmente especializado y técnico para esta criba, para este matiz, podríamos correr el peligro, según esta prensa, de

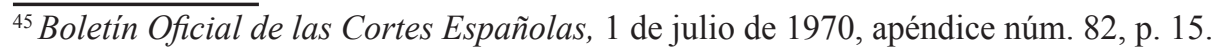

${ }^{46}$ Boletín Oficial de las Cortes Españolas, 2 de julio de 1970, apéndice núm. 86, p. 12.

${ }^{47}$ Ibidem, p. 20.

${ }^{48}$ Ibídem, p. 21.

${ }^{49}$ Ibídem.
} 
que esto fuera una caza de brujas, una caza de homosexuales, una caza de prostitutas, y éste no es el tema. Esta ley no va a desencadenar una persecución contra ningún tipo de ninguna clase. Lo que hace es establecer unos indicios de peligrosidad, y después una competencia de un tribunal especializado para ver en cada caso cuando hay verdadera peligrosidad y cuando no la hay. ${ }^{50}$

El 28 de julio de 1970, se presenta en Comisión los fundamentos del dictamen, y es Gómez de Arana el encargado de hacerlo. En su ponencia expone las vicisitudes del debate y diserta sobre los conceptos de peligrosidad y prevención entre otros. A la hora de abordar el problema de la homosexualidad, aporta unas reflexiones interesantes enmarcadas en el deber público de protección del bien común:

El tema de la homosexualidad es difícil y oscuro. Se le ha calificado como el talón de Aquiles de la ciencia sexológica. Hoy se distingue comúnmente entre la aberración y la perversión. Aberración o error -etimológicamente de «aberratio», «aberrare», andar errante-; el homosexual yerra respecto a la relación biológica natural de los sexos; y perversión del verbo «perverto», de «per»y «verto», destruir. La perversión supone la destrucción de la personalidad, la caída en la sensualidad, la promiscuidad, el enviciamiento. La sociedad, como decíamos, debe procurar interrumpir el circuito de la perversión. Y no se diga que estas situaciones son incurables, porque si, en efecto, sería discutible que podamos obtener una reestructuración, o como queramos llamarle, de las esferas vivenciales instintivas -esto es, convertir a un homosexual en heterosexual-, en cambio, sí podemos llegar a detener la perversión y evitar que el homosexual cause daño a la sociedad. ${ }^{51}$

Ese mismo día se aprueba el texto en las Cortes por unanimidad, y con fecha de 4 de agosto de 1970, la LPRS fue aprobada, refrendada por el jefe del Estado. El texto argumentaba que su voluntad no era castigar, sino "proteger y reformar a «las personas caídas al más bajo nivel moral»" ${ }^{52}$. Siguiendo la lógica de la peligrosidad contagiosa de las homosexualidades, se crearon dos instituciones al hilo de la LPRS "para albergar a homosexuales activos (Cárcel de Huelva) y pasivos (Badajoz $)^{53}$. Pronto encontraron que estas cárceles eran insuficientes, por lo que muchos homosexuales estuvieron en cárceles comunes" ${ }^{54}$. Con la entrada en vigor de la LPRS, se dio un aumento importante en las detenciones con respecto a la LVM, y no siempre terminaban en condena, entre otros motivos por la superpoblación en la cárcel ${ }^{55}$. En los centros

\footnotetext{
${ }^{50}$ Boletín Oficial de las Cortes Españolas, 7 de julio de 1970, apéndice núm. 88, p. 29.

${ }^{51}$ Boletín Oficial de las Cortes Españolas, 28 de julio de 1970, núm. 2, p. 57.

${ }^{52}$ Huard, Geoffroy, Los antisociales. Historia... op. cit., p. 97.

${ }^{53}$ También se creó una colonia agrícola de internamiento específico para pervertidos en Tefia, isla de Fuerteventura. Ramírez Pérez, Víctor M., "Franquismo y disidencia sexual. La visión del ministerio fiscal de la época”, en Aposta. Revista de Ciencias Sociales, 77 (2018), p. 146.

${ }^{54}$ Platero, Lucas, "Lesboerotismo y la masculinidad... op. cit., p. 22.

${ }^{55}$ Huard, Geoffroy, Los antisociales. Historia... op. cit., p. 101.
} 
para pervertidos, que tenían una regulación organizativa específica ${ }^{56}$, se aplicaban técnicas psicoterapéuticas como tratamiento correctivo, y se mantenía a los presos ocupados ${ }^{57}$ “ $\operatorname{cosiendo}^{\circ}$ balones o con actividades semejantes" ${ }^{58}$. La ley, además de estipular medidas privativas de libertad, cuya duración no se especificaba, pero se sabe que podía alcanzar los tres años ${ }^{59}$, también prohibía el regreso a la residencia, a la ciudad de origen, durante cinco años tras la condena. A esto se le añade la obligación de declarar el domicilio habitual, notificar cualquier cambio y respetar la "Prohibición de visitar establecimientos de bebidas alcohólicas y los lugares donde se hayan desarrollado las actividades peligrosas" ${ }^{\prime 0}$.

\section{Conclusiones. Proselitismo, propaganda y estigma social}

Durante la década de los 70, y de manera paralela a las negociaciones políticas que se produjeron para instalar la democracia, un nuevo modelo de ciudadanía fue también renegociado; y las cuestiones relativas al género y al sexo salieron a primera línea de debate. Fueron, además, objeto de explotación por diversas formas de expresión de la cultura popular que, tras la abolición de la censura, vieron la oportunidad de comercializar imágenes prohibidas durante casi cuarenta años $^{61}$. Esto, como se ha dicho, ocurría a la vez que aumentaban las redadas y detenciones por peligrosidad social, lo cual supone una muestra más de la tensión que caracterizó el tránsito a la democracia. En lo que refiere al espectro legal, la urgencia del activismo era, lógicamente, la despenalización, y entre los juristas comenzaba a haber ya diversidad de opiniones, aunque las resistencias a la libertad eran considerables ${ }^{62}$.

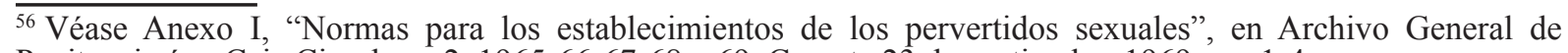
Penitenciarías, Caja Circulares 2, 1965-66-67-68 y 69, Carpeta 23 de septiembre 1969, pp. 1-4.

${ }^{57}$ La "laborterapia o terapéutica del trabajo", comentada en Cayuela Sánchez, Salvador, Por la grandeza... op. cit., p. 259, y recogida como parte del proceso de rehabilitación de los "invertidos" en el Anexo I, era la práctica sistemática a la que se les sometía en las prisiones. Las llamadas "terapias correctivas" (aversivas, electroshocks, etc.), consistentes en asociar imágenes homoeróticas a impulsos dolorosos para "reconducir" los deseos, no parece que se implementara en cárceles, aunque sí estaba avalada y recomendada por autoridades como Sabater Tomás y experimentada por doctores como Masana y Cirera, pero en consulta privada. Ver Mora Gaspar, Víctor, Al margen de la naturaleza... op. cit., Molina Artaloyita, Francisco, Estigma, diagnosis e interacción... op. cit., y Baidez Aparicio, Nathan, Vagos maleantes... y homosexuales. La represión a los homosexuales durante el franquismo, Barcelona, Malhivern, 2007.

${ }^{58}$ Tal y como relata el exrepresaliado Antoni Ruiz en el documental: Vallejo, César y Paco Tomás (dirs.), Nosotrxs somos. Amarillo. Enfermos y Peligrosos, Madrid, Radio Televisión Española, 2018, min. 5-6.

${ }^{59}$ Huard, Geoffroy, Los antisociales. Historia... op. cit., p. 97.

${ }^{60}$ Boletín Oficial del Estado "BOE”, núm. 187, de 6 de agosto de 1970, páginas 12.551 a 12.557.

${ }^{61}$ Revistas divulgativas de contenido erótico y periodístico, como Interviú o Party, o la producción de películas de lo que se llamó el cine del destape. Sobre el cine de los 70 como espacio de enunciación de sexualidades subalternas, ver Melero, Alejandro, Placeres ocultos. Gays y lesbianas en el cine español de la transición, Madrid, Notorius, 2010.

${ }_{62}^{2}$ La entrada en vigor de la LPRS fue una de las razones principales por las que se creó el activismo organizado por la liberación homosexual. "Por lo que respecta al movimiento gay/lesbiano en España, este no puede concebirse sólo como un movimiento expresivo de afirmación identitaria. Desde sus inicios en el tardofranquismo, ha tenido también un elevado componente de lógica instrumental tratando de modificar e impulsar disposiciones legales a favor del colectivo homosexual." Monferrer Tomás, Jordi M., "Movimientos sociales y cambio social. El proceso
} 
En 1977, el mismo año que se celebró la primera manifestación por la liberación homosexual en España, se publicó el interesante volumen Los homosexuales frente a la ley. Los juristas opinan, una obra coordinada por Victoriano Domingo Loren, compuesta por entrevistas a juristas españoles sobre la polémica cuestión. La más destacada, quizá, sea la realizada a Sabater Tomás, responsable de la redacción del proyecto de la LPRS. En 1977, modifica ligeramente sus motivaciones y explica que lejos de querer "perseguir" a nadie, de lo que se trata es de rehabilitar y hacer la vida fácil a los homosexuales. Sabater Tomás se declara artífice máximo de la ley y conocedor profundo del tema. "El tratamiento que hay que dar a un peligroso social no puede ni debe ser el mismo que se da a un delincuente común. No se trata de castigar, sino de curar, de reinsertar a un individuo en la sociedad, de educar." ${ }^{93}$ Explica que la modificación de la LVM en 1954 se debió a un "aumento de la homosexualidad" 64 y muestra su grave irritación con que la LPRS no considere per se al homosexual como peligroso; lo de los "actos" homosexuales le parece una contradicción ${ }^{65}$. El mayor problema, indica Sabater Tomás, es que "puede ser degeneración”, pero normalmente es enfermedad, y es contagiosa; $\mathrm{y}$, ante la perplejidad del entrevistador, explica que "más que de contagio habría que hablar de proselitismo"66. En este momento asevera que es así como había que entender sus textos, que no se refería a "contagio" literalmente, sino al proselitismo de forma de vida homosexual. El contagio era solo una metáfora, una forma de hablar. Con todo, Sabater Tomás se exime de cualquier tendencia ideológica ya que asegura varias veces que los penalistas son un mero reflejo de la forma de pensar de la sociedad; y tal y como piensa la sociedad a los homosexuales solo les queda la abstención o realizar actos de manera tal que nunca puedan llegar a conocimiento público, aunque esto en sí mismo le parece una contradicción y un peligro potencial. Para terminar, enumera métodos de reconversión llevados a cabo por colegas en clínicas españolas y alaba sus resultados.

Probablemente el giro más interesante en el discurso de Sabater Tomás lo constituye el hábil intercambio entre "contagio" y "proselitismo". Las lógicas del lenguaje franquista, que produjeron conocimientos y prácticas durante décadas, habían quedado obsoletas; y de la misma manera que la LVM ya no funcionaba para las exigencias de los 70, el lenguaje común debía adaptarse a las nuevas realidades. Con este giro, Sabater Tomás había abierto una vía nueva y llamativa para las posibilidades de continuación de las políticas represivas contra la sexualidad subalterna. Dado que considerar la homosexualidad una "enfermedad contagiosa" ya no era sostenible, hablar de proselitismo garantizó la reproducción del estigma

\footnotetext{
de cambio de la agenda política impulsado por el movimiento gay/lesbiano en España", en XXVII Congreso de la Asociación Latinoamericana de Sociología. VIII Jornadas de Sociología de la Universidad de Buenos Aires, Buenos Aires, Asociación Latinoamericana de Sociología, 2009, pp. 2-3. Disponible en «https://www.aacademica. org/000-062/1572» [consultado el 24 de julio de 2018].

${ }^{63}$ Domingo Loren, Victoriano, Los homosexuales frente... op. cit., p. 123.

${ }^{64}$ Ibídem, p. 124.

${ }^{65}$ Ibídem.

${ }^{66}$ Ibídem, p. 125.
} 
y el discurso discriminatorio. Ya no se trata de "contagio" y de "curaciones", el lenguaje se renueva y sustituye estos conceptos por "proselitismo social" y reconversiones o "cambios de conducta". La idea del "proselitismo", heredera directa del discurso biopolítico patologizante del "contagio" y de la necesidad de exclusión por el bien y la higiene (moral) de la sociedad, cala más profundo de lo que en principio pudiera parecer. Durante esta década se comenzará a manejar el concepto de "propaganda homosexual" o "propaganda del homosexualismo" como forma de marcar el límite de las concesiones que se les podía hacer a los frentes de liberación homosexual y a sus exigencias de igualdad. Será una constante por parte del sector continuista del franquismo, pero también por parte de representantes muy notorios de la izquierda, como se expone en el útil volumen Los partidos marxistas. Sus dirigentes, sus programas, también publicado en 1977. En él se recogen entrevistas realizadas a líderes de la izquierda, y se les pregunta sobre temas polémicos como la homosexualidad. Algunos (comunistas y anarquistas fundamentalmente) leen la situación de marginalidad sexual como un elemento injusto, propio de la represión que hay que combatir; y otros, más o menos equivalentes en número, muestran grandes resistencias. Destaca Enrique Tierno Galván, del Partido Socialista Popular, por el uso del argumento del proselitismo ${ }^{67} \mathrm{y}$, especialmente, por el enfoque de las libertades sexuales como amenaza a la estabilidad política:

Se trata de personas que han desviado los instintos bien por razón biológica, por razón social o, en muchos casos, porque no han tenido un tratamiento psiquiátrico a tiempo [...]. La homosexualidad debe ser corregida porque realmente no responde a los principios de una sociedad estable como se entiende [...]. En una sociedad libre, bien educada, en la que el psiquiatra y el psicólogo desde el principio están de acuerdo en las exigencias normales de la sociedad y en lo que ésta pide, ese fenómeno desaparecerá o tenderá a desaparecer [...]. Hay un consenso general que admitir. Y en las épocas de transición creemos que debemos defender actitudes claramente ascéticas: si empezamos a flaquear, a hacer concesiones y a romper determinadas limitaciones ascéticas, el proceso revolucionario se puede desgastar, romper y faltar a sus principios elementales [...]. No podemos admitir estas concesiones de derechos a fórmulas ambiguas de relaciones. ${ }^{68}$

Sin embargo, el trabajo de la colectividad organizada por la liberación homosexual obtuvo finalmente resultados legales. La aprobación en diciembre de 1978 de la Constitución española aceleró la reforma de la LPRS, "por vía de urgencia, en la Ley 77/1978 de modificación de la [LPRS], con una reforma legal en la que se eliminaron varios artículos de la misma" ${ }^{69}$. Por ley

\footnotetext{
${ }^{67}$ Argumento que ese mismo año ya había utilizado en una polémica entrevista que concedió a la revista Interviú, en la que hablaba de la necesidad de "erradicar la propaganda homosexual" en favor del "consensus generalizado de Occidente". Foncuberta, Mar, "El mono desnudo. Enrique Tierno Galván. Presidente del Partido Socialista Popular”, en Interviú, 29 (1977), Barcelona, Grupo Zeta, p. 37.

${ }^{68}$ Ruíz, Fernando y Joaquín Romero, Los partidos marxistas. Sus dirigentes, sus programas, Barcelona, Anagrama, 1977, p. 145.

${ }^{69}$ Ramírez Pérez, Víctor M., "Franquismo y disidencia sexual... op. cit., p. 167.
} 
del 26 de diciembre de 1978, se anularon del reglamento, entre otras pequeñas modificaciones, los supuestos que afectaban a los "actos de homosexualidad" " la despenalización no quiere decir que las personas de sexo y género disidente disfrutaran de igualdad de reconocimiento, ni que la situación de no-ilegalidad formal supusiera dejar de ser perseguidos o rechazados en muchos contextos, o que la accesibilidad al desarrollo laboral no continuase limitada y dependiese siempre de su identidad específica ${ }^{71}$ y de la intersección con otras variables como la clase social o el estatus. Tampoco significó que se llevara a cabo una revisión crítica de las jerarquías biopolíticas impuestas ${ }^{72}$, ni una reestructuración o una reparación.

La despenalización, no obstante, fue una fundamental y remarcable victoria del activismo español por la liberación homosexual, y supuso el comienzo de otra etapa ${ }^{73}$ que demandaba la reelaboración tanto de los propios objetivos del activismo como de los nuevos significados de la identidad sexual disidente en el contexto pragmático posconstitucional. No obstante, y con independencia de ello, es destacable que los expedientes por peligrosidad fueran archivados de manera definitiva en los años $80^{74} \mathrm{y}$, algunos de ellos, en la segunda mitad de la década. Según señala Chamouleau, es importante leer esta cuestión como "rastros de discursos institucionales, estatales, sobre individuos que siguen arrastrando un estigma impuesto por el Estado cuando ya se ha consolidado el orden democrático" 75 .

¿Qué otras huellas o rastros del sistema de organización biopolítica franquista permanecen? Puede que sea esta la pregunta que cabe plantear como parte de la conclusión. El concepto de "proselitismo" es, de hecho, uno de los vestigios simbólicos del discurso hegemónico franquista sobre homosexualidades que ha permanecido bajo distintos significantes, apuntando siempre a la disidencia sexual como amenaza para la norma y el bien común. Las ideas del "contagio social", la "propaganda homosexual" o "propaganda del homosexualismo" (o la amenaza ante el exceso de visibilización, etc.) son elementos que sirven para reproducir los límites discriminatorios de la organización biopolítica de la dictadura; y su reproducción se produjo

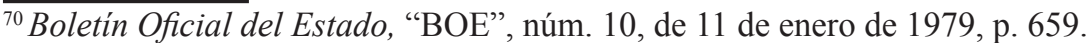

${ }^{71}$ A este respecto, Trujillo señala que "lesbianas y gais, no obstante, tuvieron percepciones distintas acerca de las implicaciones de la derogación de la ley [...]. La invisibilidad y ausencia de imágenes de lesbianas en general, y masculinas en concreto, difícilmente podría haber sido de otra forma en aquellos años, si pensamos en todos los mecanismos de control y vigilancia férrea sobre los roles de género y sobre las sexualidades, especialmente de las mujeres, heredadas de la dictadura", Trujillo, Gracia, "Archivos incompletos. Un... op. cit., p. 45.

${ }^{72}$ Además, "sí mantiene disposiciones punitivas contra la prostitución y mantiene firme la expresión de normas de «convivencia social», respecto de la que se definen a los «desviados» o peligrosos sociales, en adelante regida por el orden constitucional de 1978". Chamouleau, Brice, Tiran al maricón. Los fantasmas queer de la democracia (1970-1988). Una interpretación de las subjetividades gais ante el Estado español, Madrid, Akal, 2017, pp. 145146.

${ }^{73} \mathrm{El}$ activismo español, cuyas organizaciones fueron siendo legalizadas ya en la década de los 80, "varió sus estrategias desde la radicalidad hacia planteamientos más reformistas", Villaamil, Fernando, La transformación de la identidad gay en España, Madrid, Catarata, 2004, p. 19.

${ }^{74}$ Los tribunales se desmantelarán definitivamente a mediados de los 80 y la LPRS no desparecerá del Código Penal hasta 1995. Boletín Oficial del Estado, "BOE", núm. 281, de 24 de noviembre de 1995, pp. 34.057-34.058.

75 “Expedientes cerrados en 1977 sólo se archivan definitivamente en 1987: La dilatación de los trámites, de varios meses o años, en este caso da cuenta del cada vez menor interés judicial por esas vidas." Chamouleau, Brice, Tiran al maricón... op. cit., p. 228.
} 
incluso desde representantes de proyectos políticos antagónicos, como hemos visto. Cabe por tanto preguntarse si en la etapa que comenzó tras la despenalización, y que todavía perdura, utilizamos significantes cuya carga semántica remite a la organización biopolítica franquista, y si su huella impregna nuestra pragmática cotidiana y nos condiciona a la hora de elaborar una visión o una lectura de sexualidades y corporeidades no normativas, propias o ajenas.

ANEXO I

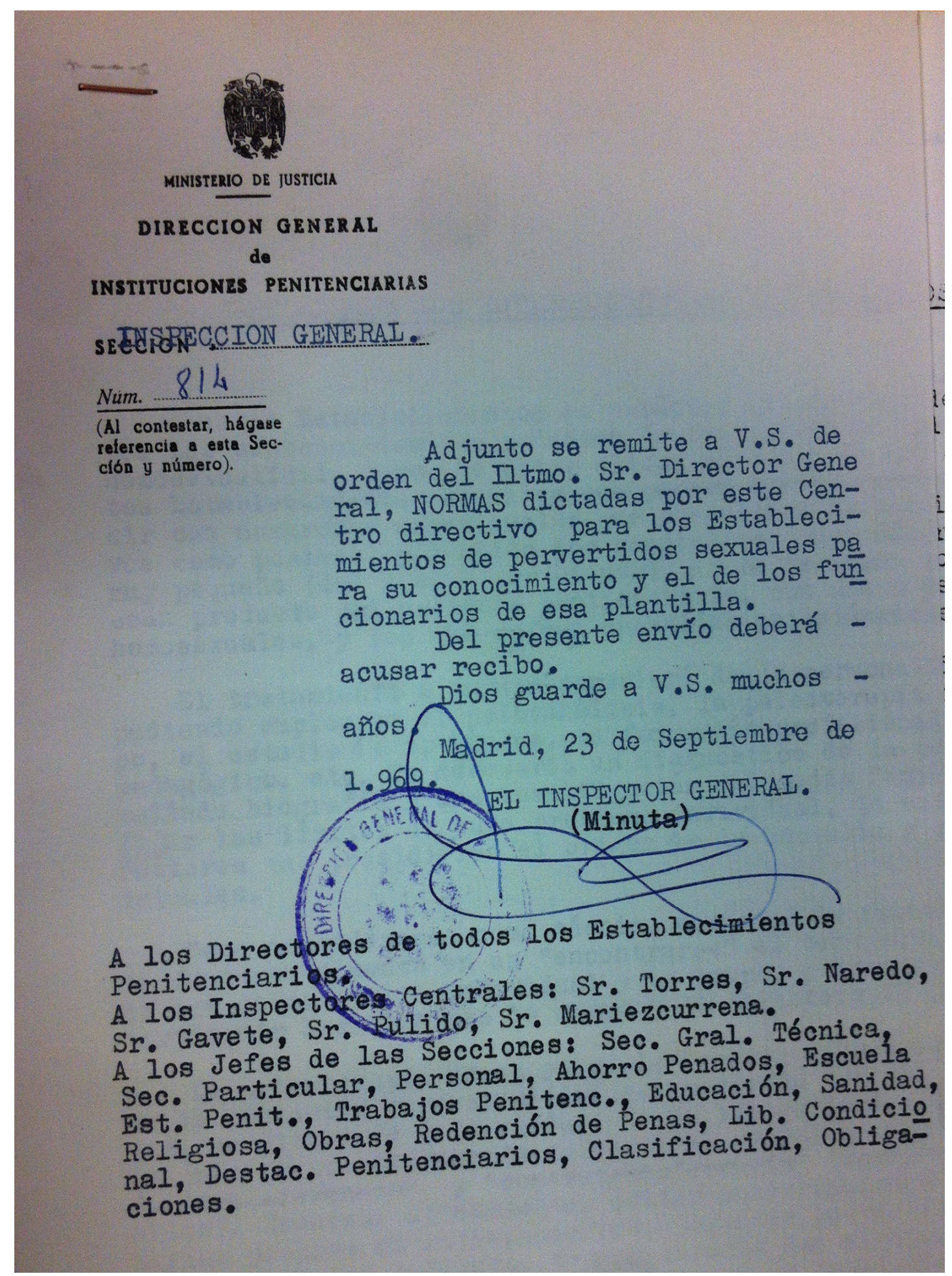




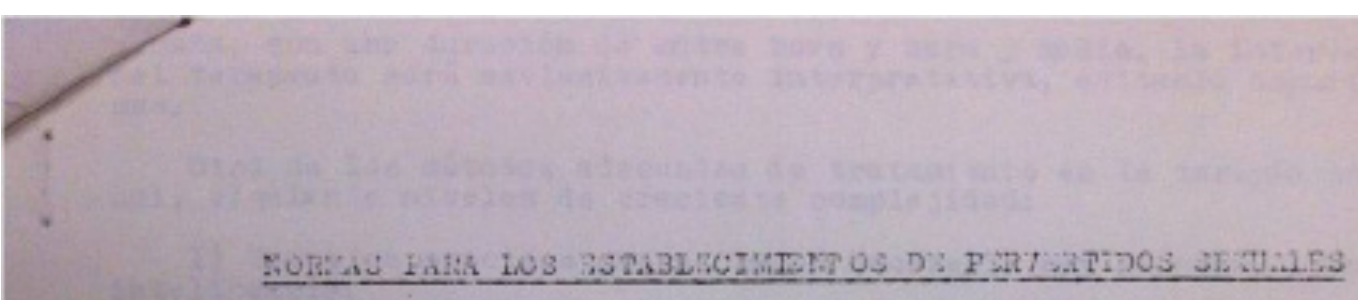

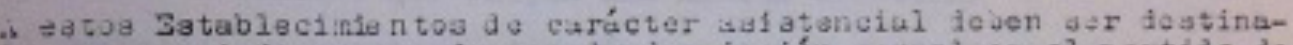
log loo dontmoiadon qus pudezean do desviueión gexual en el aentido de homoge.uylidud. I ro, le antro elloa, sóio haz de ser deatinudos a ea-toa Latabiecinientos aque $110 a$ que juadun considerarse habstualea, ea de cir con numeroase exuerienciua the gonsolidan la desviación (tanto actI vos como pasivos) y tumblén 103 congénitos, cuyo número actualsente ea

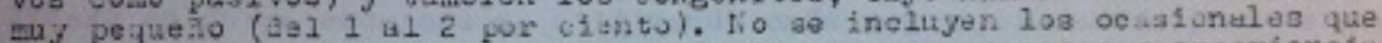

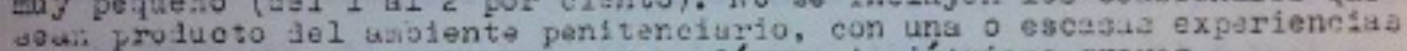

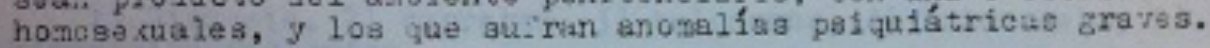

51 tratumiento a seguir deponderś de la personulidad de cado interno, puacendo emplowrse el psicosnélisis, la paicotorujis individusl y de eru po, el eatudiode aptitudea, la for dación profesional, el control peicopejagógico, etc. Ds necosirio un ilagnóstico de la persunalidad, una detollada biorrafia $y$ una investicación del ledio f́miliar $y$ social psra = fijar los linitea de ctida problema individual, la estructira del yo, loa factoras qu: pr:ajajeron el urigen de la anowála y las circunatancias = actualea.

Debe considerarae como tícnica eaercial la paicoterapia, que conaiste firdanentalisente en un "encontrarse" el terspeuta con al puciante. Tue de ser paicoterapia inaividual y de grupo, $y$ dentro de la prinera hay que 11 atinguir las ténias do apoyo y la pascotarapis profunda.

La picoterapia de apoyo suele buaurae ex entreviatus esclarecodoras de la sitasatón $y$ personalsagd del puciente que, al iubler de aua proble mas, ge libers le la aisiudod, de la inazguridad $y$ del sentiviento de chl pa plad el jelootompeuta rofuerza el jo lel piciente aediunte fenómeno pa plua cl "contratranaferencia" (corrientes afectivas entre ellos). Bacuchas atentanente, evitar interrupcione s innecesarias $y$ coaen turios propios no insispensubles, jeriltir la rentilación de conflietos tare prop el pro jio terapeata aaté convencido, $y$ todo ello reslizudo en uns atmófera co plo terapeuta eate eonvencido, fine, son 103 principios curdumentales de eg ta paicoterapia de apoyo.

Ia pjicoterapia profunda ae regerva para casoz especiules y sólo debe lle rurae a cubo por eapecialistas con probada reaponaabilidad moral y profesional. La paicoterupla de grupo es aconsejuble cuande se cuentu =

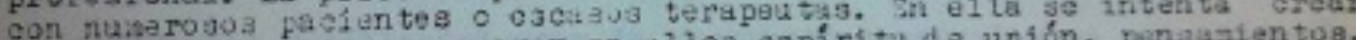
srapos de inturnos $y$ promover en $\$ 1100$ eapiritu do unión, ponaumentos,

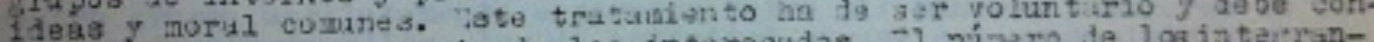

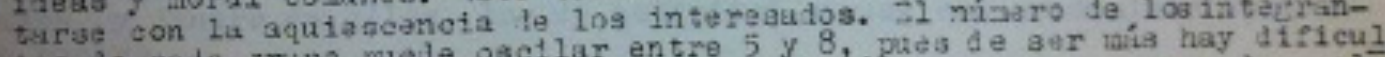
tes de cada zripo puede oscliar entre 5 y 8 , pues de avr a que cuda cual tudes para una integrución adecuifa $J$ faltara tiapo pura que es serior, el

expunza sus problemas e ileas. For otra ja rte, ai

Convtene udvirtiz que on el grupo no de ven aur tncluidas peraonaa ex al, pues su rolación podía ger eauaa inhib? torta para la cortunt cución espontánes $y$ franca $y$ por zue pueje dnrae lupars la counica un subgrupo, 10 que seria perjulicial para la inte

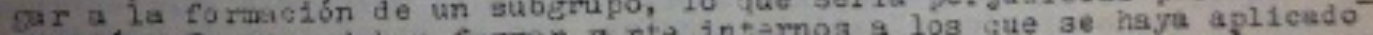

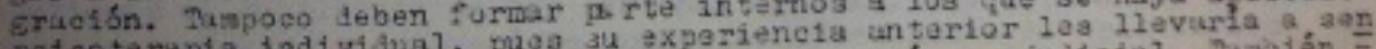

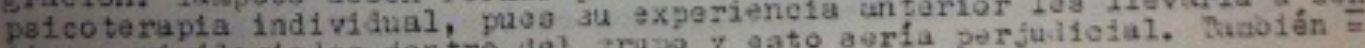
tirse privilazialos dentro del zrapo $y$.

deben excluirae 203 doprealvos aevaroa. os integrantes serún alejiloa jor 41 terapeuta fendendo en elaente 
dana, con uns durución de entro hora $y$ hors $f$ media. Ia intervención del terapeuta será excluaivanente interpretativa, evitundo 1mpartir nor nas.

Otro de los mótodos adecualos de tratamionto es la teripla ocupacia nal, siguiento niveles de creclente complejidad:

1) Trabajos precisos que no hagun necesuria una excesiva atención ni intelicencia.

2) Tareas racúnicas que exijan una afinina utorción.

1) Trabajos q̨ue precisen atención conatante y oiarta iniclativa.

1) Trubajoa aludiares a 103 de los obrerus normales.

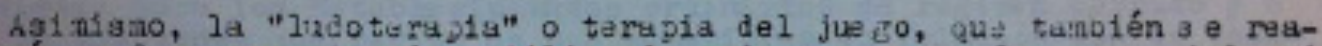
lizsrí en forna escalonada, utilizando cada vyz a yor fue rza $\mathrm{j}$ violencia:

1) Simnusia, 2) carrerua, 3) balonmano, 4) balonoeato, 5) futbol y ejereicioa violonto:3.

Por Ĺltimo, la luborterapia, que puede infciarae en niveles auperfic1alea con el lavado y fregado, paaando luego a la jardinería $y$ horticil turs.

Las normas que tian de regir en $10 s$ Zstublectmlentos para pervertilos sexuslas son 14n alculentes:

1.- Los homosexusle a habitualea, congénitiog o adquiritos, que hayan a1to sentencla los deben, on sualiuler caso, ser propuestos para au claa1ficteín a la Jentrul de observsción.

2.- Los homosexusles ocisalonales, tanto activos como pusivos, que isualmente hayan aldo sentencludoa deben aer propuestos para yu deatino a Estuble cimientos ortinarios de régizen cerrado, con advertencis de viGlinesa extromata on 1 a esfera jexual.

3.- Los intarnva homosecualea, tanto ociatonules como habituales, que peifezcun paicogstias gruve deben ser projueatos para Catablecimien tos de pelóputas. Los que padezean otrostipos de trastomos polquicos, para el janatorio paiquí́trico penitenciar1o. Del misno modo, desen aer propueatos para el Jetublecimionto de alcoh́́licos $\mathrm{J}$ toxicśanoa loo internos homodsxtules aftectulos por el ulcoholisao $f$ toxiconanisa. Los in

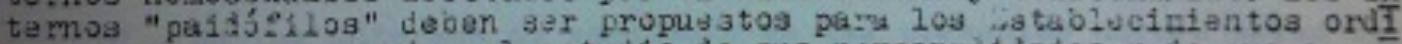
nurija que correapondin al astudio de sus personalilades $y$ de ua expe= dientea pensles $y$ pent tencti rius. Ius liama los "prostitutos" debe aer

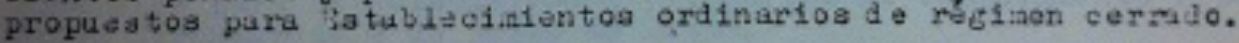

4.- - in 203 7utublocitui nntos de pervertilog sexuales se jatablecerín cuatro erupos aboolutazente de parados entre aí: menorea y majores de 21 axoa, $y$ tentro de ellos, 103 de actividad aecual con prodoalnio activo o pustro.

5.- \$1 rácicen cara 103 diferentes grupos on los Tatubltcimientos de pe rvertidos ae sniles debe ser análogo al cerrado, con zajor o menor acentuactón didoiplina ria de dicho réciaen secún lo aconaejen las peculiarilades de los isferentea srupos.

6. - No obatunte 10 inaicudo en la norma anterior, loa internoa propuestog para elevactón al dezundo grido del sistena progreaivo poirán continuar ol cumpliento de sua condenas en los Zstabieciaientos de per vertilos sexiales cuando asf 10 aconsejen neceaidadoa to tratamiento. 


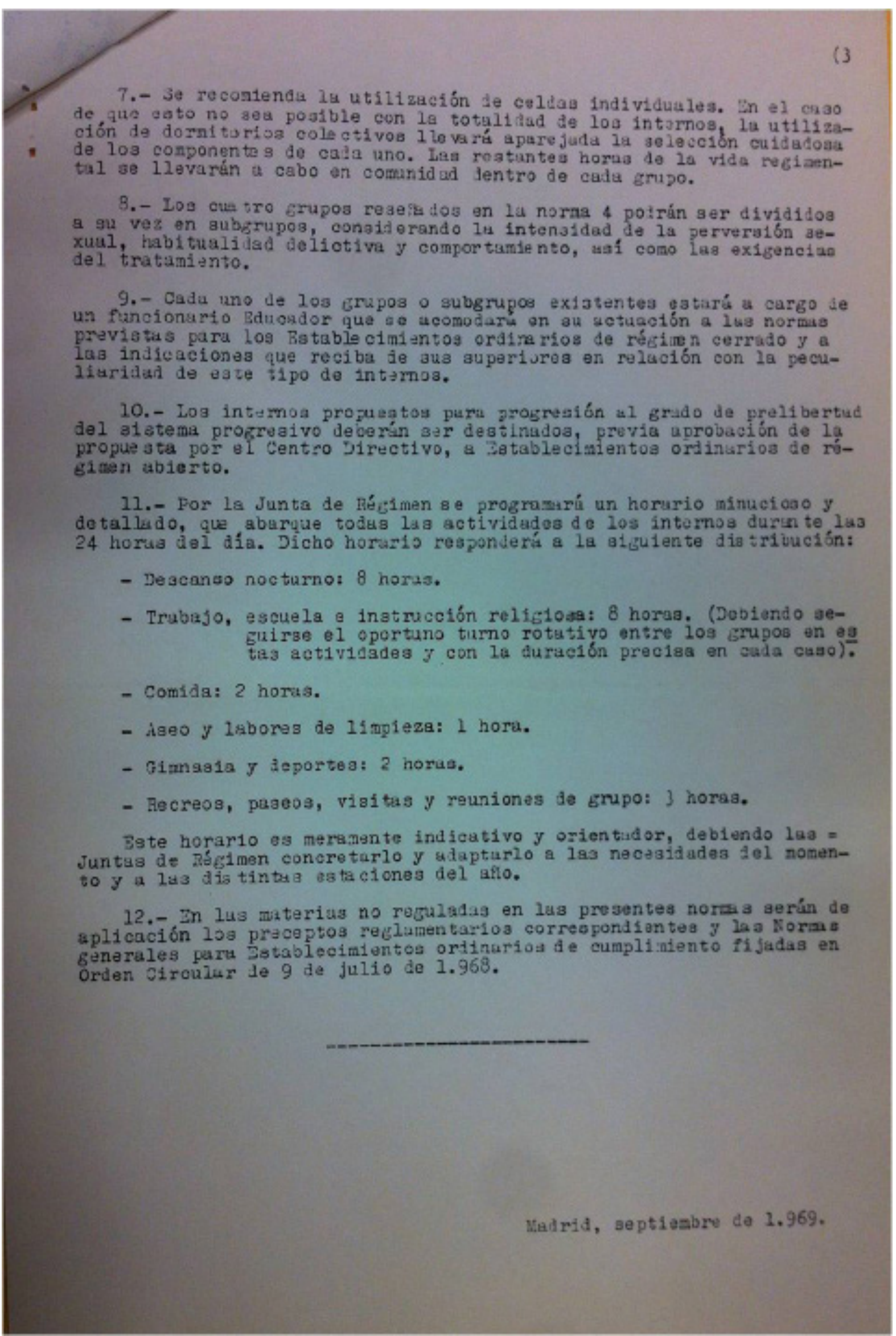

